\title{
DETERMINATION OF TECHNICAL AND ECONOMIC PARAMETERS OF AN IONIC TRANSPORT MEMBRANE AIR SEPARATION UNIT WORKING IN A SUPERCRITICAL POWER PLANT
}

\author{
Janusz Kotowicz*, Sebastian Michalski, Adrian Balicki \\ Silesian University of Technology, Institute of Power Engineering and Turbomachinery, 18 \\ Konarskiego Street, 44-100 Gliwice, Poland
}

\begin{abstract}
In this paper an air separation unit was analyzed. The unit consisted of: an ionic transport membrane contained in a four-end type module, an air compressor, an expander fed by gas that remains after oxygen separation and heat exchangers which heat the air and recirculated flue gas to the membrane operating temperature $\left(850^{\circ} \mathrm{C}\right)$. The air separation unit works in a power plant with electrical power equal to $600 \mathrm{MW}$. This power plant additionally consists of: an oxy-type pulverized-fuel boiler, a steam turbine unit and a carbon dioxide capture unit. Life steam parameters are $30 \mathrm{MPa} / 650^{\circ} \mathrm{C}$ and reheated steam parameters are $6 \mathrm{MPa} / 670{ }^{\circ} \mathrm{C}$. The listed units were analyzed. For constant electrical power of the power plant technical parameters of the air separation unit for two oxygen recovery rate $(65 \%$ and $95 \%)$ were determined. One of such parameters is ionic membrane surface area. In this paper the formulated equation is presented. The remaining technical parameters of the air separation unit are, among others: heat exchange surface area, power of the air compressor, power of the expander and auxiliary power. Using the listed quantities, the economic parameters, such as costs of air separation unit and of individual components were determined. These quantities allowed to determine investment costs of construction of the air separation unit. In addition, they were compared with investment costs for the entire oxy-type power plant.
\end{abstract}

Keywords: four-end type ionic transport membrane module, air separation, supercritical power plant

\section{INTRODUCTION}

Reduction of greenhouse gas emission is the most significant challenge for energy sector in the 21st century. This emissions have greatly influenced climate change that the world has faced. Carbon dioxide is one of such gases. It is formed in huge amounts during combustion of fossil fuels. Despite this, the share of the fuels in energy production will remain significant over the next 20 to 30 years. Natural gas and both hard coal and lignite are such fuels. The first (fuel) is more favorable in terms of $\mathrm{CO}_{2}$ emissions, because about 2.5 times less carbon dioxide is formed during combustion compared to both coals. However, hard coal and lignite have a greater importance due to the fact that in the world there are large and evenly distributed resources of coal. Currently, about $39 \%$ of global electricity is generated using these fuels. In 2012 in Poland this share was at around 83\% (134.6 TWh of the total annual production equal to 162.1 TWh) (The Energy Market Agency, 2013). It is expected that in 2030, $57-67 \%$ of Polish electricity will be generated with the use of coal technologies. Therefore, it is necessary to develop new power plants that allow for a radical reduction of $\mathrm{CO}_{2}$ emissions. This objective can be achieved with the use of the following technologies: pre-combustion, post-combustion 
and oxy-combustion. However, the introduction of these technologies is related with a significant increase of auxiliary power of power plants (Kotowicz and Janusz, 2007).

Removal of $\mathrm{CO}_{2}$ in pre-combustion technologies is closely associated with IGCC (Integrated Gasification Combined Cycle) power plants. During the gasification process occurring in the reactor, coal reacts with oxygen and steam forms a synthesis gas (syngas) as a result (Janusz-Szymańska, 2012; Kotowicz et al., 2013; Piptone and Bolland, 2009; Skorek-Osikowska et al., 2012a; Skorek-Osikowska et al., 2014). The composition of the gas is dependent on the type of gasification unit, but the main components are $\mathrm{CO}, \mathrm{H}_{2}, \mathrm{CO}_{2}$ and residual $\mathrm{N}_{2}$. In a water-gas reactor (so-called a "shift reactor") $\mathrm{CO}$ is converted with the use of steam to $\mathrm{CO}_{2}$ and $\mathrm{H}_{2}$. Then, carbon dioxide is separated from syngas before entering the combustion chamber. This separation is performed with several methods, such as adsorption, membrane separation, chemical and physical absorption.

Post-combustion methods are based on the separation of carbon dioxide from the flue gas formed during combustion of fuels. The main components of the flue gas are nitrogen and carbon dioxide. Their separation is the primary task of a carbon dioxide capture (CC) unit used in post-combustion technologies. Separation involves chemical absorption (mainly 30 percent solution of MEA or MDEA) (Bartela et al., 2014; Piptone and Bolland, 2009; Skorek-Osikowska et al., 2012b) and membrane separation with relatively cheap membranes (Janusz-Szymańska and Kotowicz, 2011; Kotowicz et al., 2010; Kotowicz and Janusz-Szymańska, 2010; Kotowicz and Janusz-Szymańska, 2011) for $\mathrm{CO}_{2}$ capture. The main advantage of these technologies is simple integration of CC unit with currently exploited power plants.

In the oxy-combustion technologies oxy-type boilers are used. In such boilers a gas formed from flue gas mixed with oxygen is fed to the combustion chamber instead of air (as in conventional boilers). In order to create these gases, mixing of the recirculated (dedusted) flue gas and oxygen produced in air separation unit (ASU) is used. Combustion process performed in this technology eliminates a so-called nitric ballast in flue gas and produces $\mathrm{CO}_{2}$-rich flue gas, and, as a consequence, greatly simplifies the process of carbon dioxide capture. The main disadvantage of this technology is the necessity of providing oxygen with suitable purity for the combustion process. Technologies of oxygen production use all available methods of gas mixture separation. One of these methods is cryogenic separation of oxygen from air (Darde et al., 2009; Dryjańska, 2013; Kotowicz et al., 2010; Liszka and Ziębik, 2010; Skorek-Osikowska et al., 2013). Currently, it is the most reliable method which can be used. However, the drawback of cryogenic separation is the use of air compressors with inter-stage cooling that require large amounts of energy. As a result, the net efficiency of the power plant is greatly reduced. The use of polymeric membranes simultaneously with a cryogenic separation unit is another method of oxygen separation (so-called hybrid, membrane-cryogenic method). This type of membrane can produce gas with a maximum of 60 percentage of oxygen. Next, the resulting gas enters a cryogenic oxygen separator. This solution greatly reduces the auxiliary power of air separation unit by reducing the flue gas flow rate at the inlet to the cryogenic separation unit. The last and also the least studied method is the use of ion transport membranes (ITM) for air separation (Bredesen et al., 2004; Engels et al., 2010; Gambini and Vellini, 2012; Pfaff and Kather, 2009). These membranes are made of oxygen ion conductors operating at a temperature of $700-900{ }^{\circ} \mathrm{C}\left(950{ }^{\circ} \mathrm{C}\right)$. With these materials it is theoretically possible to separate oxygen with a purity of $100 \%$ (Pfaff and Kather, 2009). This type of ASU has lower auxiliary power than other types of ASU because of possibility of expander implementation. Membrane modules can be divided into three-end and four-end types.

The purpose of this paper is to present the methodology designation of technical and economic parameters of an air separation unit with a four-end type ionic transport membrane module. The technical parameters are, among others: power of devices used in ASU, membrane surface area and auxiliary power of ASU. The economic parameters are acquisition costs of individual elements of the unit and total investment costs of the air separation unit. 


\section{DESCRIPTION OF THE OXY-TYPE POWER PLANT}

The analyzed oxy-type power plant consisted of the following elements: an oxy-type pulverized-fuel boiler fed by hard coal, a steam turbine unit, a carbon dioxide capture and compression (to 150 bars) unit (CC) and an air separation unit (equipped with a four-end type oxygen ionic transport membrane module (ITM) and a gas turbine unit). A scheme of the power plant is shown in Fig 1.

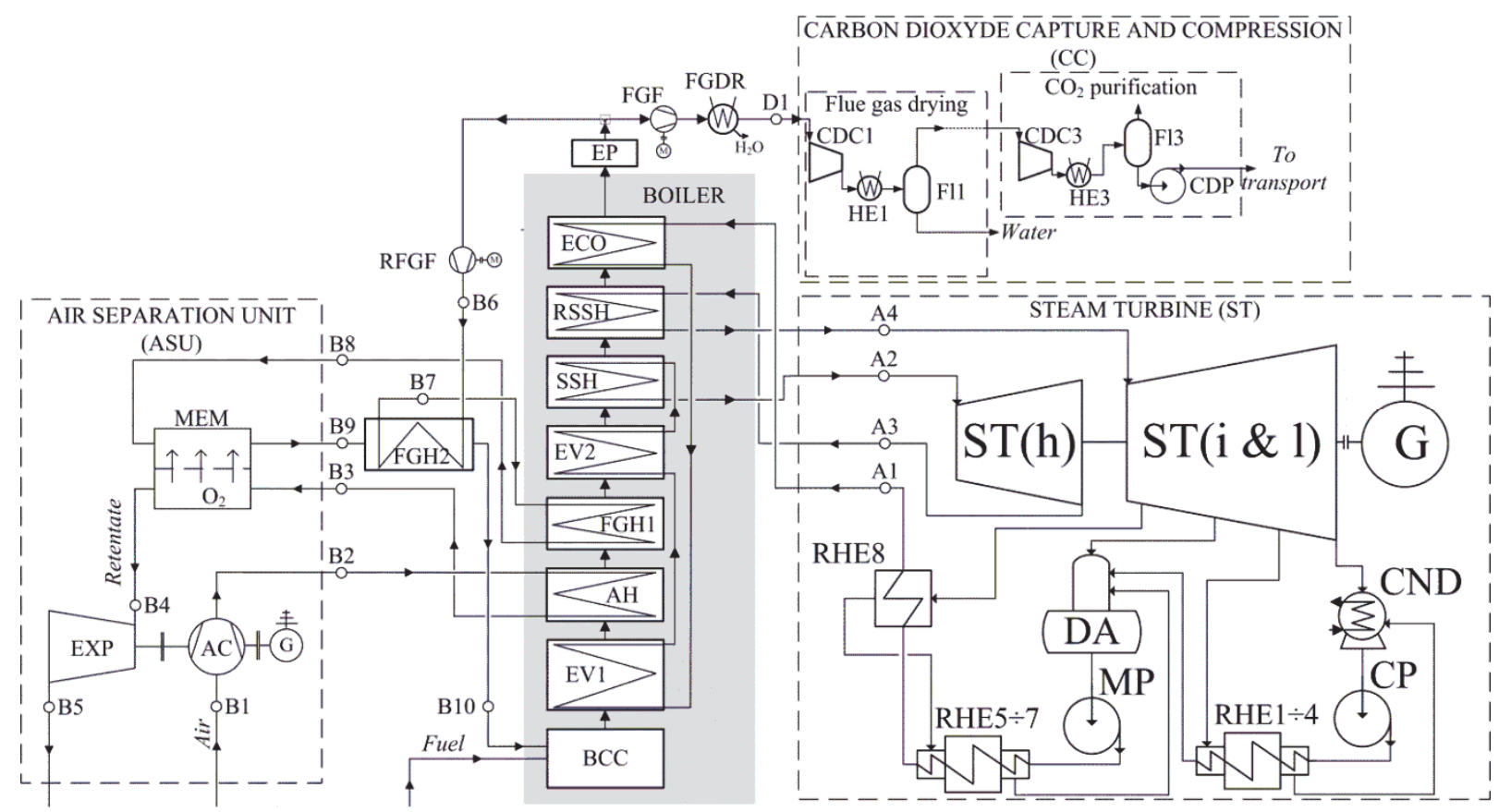

Fig. 1. Diagram of the oxy-type power plant (ST - steam turbine, (h) - high-pressure part, (i) - intermediatepressure part, (l) - low-pressure part, G - generator, CND - condenser, DA - deaerator, CP - condensate pump, MP

- main feed water pump, RHE1 $\div 4$ - low-pressure regenerative heat exchangers, RHE $\div \div 7$ - high-pressure regenerative heat exchangers, RHE8 - steam cooler, BCC - combustion chamber, EV - evaporator, AH - air heater, FGH - recirculated flue gas heater, SSH - live steam superheater, RSSH - reheated steam superheater, ECO - economizer, EP- electrostatic precipitator, FGDR - flue gas dryer, FGF - flue gas fan, RFGF - recirculated flue gas fan, MEM - membrane module, AC - air compressor, EXP - expander, CDC - carbon dioxide compressor, CDP - carbon dioxide pump, Fl - phase separator, HE - flue gas cooler)

The high-pressure part of the steam turbine, shown in Fig. 1, was fed with life steam with supercritical parameters at $650{ }^{\circ} \mathrm{C} / 30 \mathrm{MPa}$ and the intermediate-part was fed with the reheated steam with parameters at $670{ }^{\circ} \mathrm{C} / 6 \mathrm{MPa}$. Pressures of the deaerator and the condenser were equal to $1200 \mathrm{kPa}$ and $5 \mathrm{kPa}$, respectively. The temperature of water at the inlet to the boiler was equal to $310^{\circ} \mathrm{C}$. The steam turbine unit consisted of a steam superheater, four low-pressure and three high-pressure regenerative heat exchangers. The steam turbine powered the generator with electric power equal to $600 \mathrm{MW}$. In the steam turbine unit a heat flux equal to $1155 \mathrm{MW}$ was supplied to water and steam. From these two quantities efficiency of steam cycle equal to $51.93 \%$ was determined. A detailed description of the steam turbine unit is presented elsewhere (Kotowicz et al., 2011).

The pulverized-fuel boiler consisted of a combustion chamber (BCC) in which hard coal with lover heating value $L H V=24078 \mathrm{~kJ} / \mathrm{kg}$ was combusted. To this element a recirculated flue gas containing $30 \%$ of oxygen (Point B9 Fig. 1) was supplied as the oxidant. The gas flow rate was determined by oxygen excess ratio (equal to 1.2). The oxy-type boiler (as in the case of conventional boilers) was equipped with an evaporator divided into two parts (EV1 and EV2), a life steam superheater (SSH), a reheated steam superheater (RSSH) and an economizer (ECO). Some flue gas from the electrostatic precipitator was recirculated and the remaining flue gas was sent to the flue gas dryer (FGDR). The 
main function of FGDR was to maintain a constant moisture content equal to $10 \%$ in the flue gas at the outlet (point D1, Fig. 1). A detailed description of an oxy-type boiler is presented in (SkorekOsikowska and Bartela, 2010).

The carbon dioxide capture (CC) unit was divided into two parts. In the first part the flue gas was further dried and in the second part carbon dioxide was separated. The recovery rate of this gas was approximately $92 \%$. The pump installed in the $\mathrm{CC}$ unit compressed the liquefied gas with carbon dioxide content at ca. $92 \%$. The liquefied gas leaving the $\mathrm{CC}$ unit had a pressure equal to $15 \mathrm{MPa}$. The last element of the oxy-type power plant, i.e. the air separation unit, is described in detail in Chapter 3.

\section{DESCRIPTION AND THERMODYNAMIC ANALYSIS OF THE AIR SEPARATION UNIT}

The air separation unit was equipped with:

- an ionic transport membrane contained in a four-end type module,

- a gas turbine unit consisting of an expander and an air compressor.

The essential elements of the units were also: a boiler air heater $(\mathrm{AH})$, a boiler recirculated flue gas heater (FGH1) and a regenerative recirculated flue gas heater (FGH2). To the air separation unit air with parameters equal to $20^{\circ} \mathrm{C}, 101.3 \mathrm{kPa}$ and relative humidity $60 \%$ (point B1, Fig. 1) was supplied. Then the air was supplied to the air compressor (AC) with an assumed compressor pressure ratio equal to 30. During compression air was heated to the temperature of $537.8^{\circ} \mathrm{C}$ (point B2, Fig. 1). The temperature was still lower than membrane operating temperature so air was supplied to the air heater (AH) in the boiler. In this element air was heated to $850^{\circ} \mathrm{C}$ (point B3, Fig. 1). Next gas entered one of the inlets of membrane module. The module contained the ionic transport membrane with an assumed operational temperature equal to $850^{\circ} \mathrm{C}$. During air flow on one side of the membrane oxygen permeation occured. As a result, gas with low concentration of oxygen was created. This kind of gas is called retentate. Next, the retentate flowed out of the membrane module (point B4, Fig. 1). Because of high temperature and pressure the gas was supplied to the expander (EXP) where during the expansion mechanical power was obtained. The power was used to drive the air compressor. In the case of overcapacity the electric generator was additionally driven by expander and in opposite case an additional electric motor was used to drive the compressor.

The second gas used in the air separation unit was recirculated flue gas taken from the outlet of the electrostatic precipitator $(\mathrm{EF})$. The flue gas had the following composition: $\left(\mathrm{CO}_{2}\right)=60.2 \%$, $\left(\mathrm{H}_{2} \mathrm{O}\right)=34.4 \%,\left(\mathrm{O}_{2}\right)=4.6 \%,\left(\mathrm{~N}_{2}\right)=0.4 \%,\left(\mathrm{SO}_{2}\right)=0.4 \%$. These quantities were determined using stoichiometric calculations of the boiler (Skorek-Osikowska and Bartela, 2010). The thermodynamic parameters of the recirculated flue gas at the outlet of recirculated flue gas fan (RFGF) were $415.6{ }^{\circ} \mathrm{C}$ and $112.9 \mathrm{~Pa}$ (point B6, Fig. 1) . Next, the gas was directed to FGH1 and FGH2 heaters, where its temperature was raised to $850{ }^{\circ} \mathrm{C}$ (point B8, Fig. 1). Flue gas with such temperature flowed through the membrane module in counter-currently to air. Permeation of oxygen from air to flue gas took place in the ionic membrane. It was assumed that at the outlet of the membrane module the flue gas contained $30 \%$ of oxygen. Such a level is considered to be optimal for the combustion process and heat transfer in the boiler (Czakiert et al., 2012). Therefore, flue gas with such oxygen concentration was fed to the combustion chamber (BBC) in the boiler.

An important quantity for air separation unit working characteristics is oxygen recovery rate. All calculations were performed for two values of the recovery rate, equal to $65 \%$ and $95 \%$. A value of this quantity depends on the mass flow rate of oxygen permeating through membrane, $\left(\dot{m}_{O 2}\right)_{P}$ and mass flow rate of oxygen at the outlet of air compressor, $\left(\dot{m}_{\mathrm{O} 2}\right)_{B 2}$, according to the equation: 


$$
R=\frac{\left(\dot{m}_{O 2}\right)_{P}}{\left(\dot{m}_{O 2}\right)_{B 2}}
$$

Other important parameters of the air separation unit are shown in Table 1.

Table 1. Remaining parameters of air separation unit

\begin{tabular}{|l|c|}
\hline \multicolumn{1}{|c|}{ Quantity } & Value \\
\hline Isentropic efficiency of air compressor, \% & 88 \\
\hline Isentropic efficiency of expander, \% & 90 \\
\hline Mechanical efficiency of air compressor, \% & 99 \\
\hline Mechanical efficiency of expander, \% & 99 \\
\hline Electric generator efficiency, \% & 99 \\
\hline Electric motor efficiency, $\%$ & 99 \\
\hline
\end{tabular}

Auxiliary power of the air separation unit depends on the air compressor power, $N_{A C}$, the expander power, $N_{E X P}$, and alternatively on the electric generator efficiency, $\eta_{G}$, or the electric motor efficiency, $\eta_{E M}$, according to the formula:

$$
\begin{gathered}
N_{A S U}=\left(N_{A C}-N_{E X P}\right) \cdot \eta_{G} \text { for } N_{A S U}<0 \\
N_{A S U}=\frac{\left(N_{A C}-N_{E X P}\right)}{\eta_{E M}} \text { for } N_{A S U} \geq 0
\end{gathered}
$$

For this quantity there may occur a negative value when the expander's power exceeds the air compressor power. In such a case, the excess power is used to drive the electric generator and in opposite case, an additional electric motor needs to be used in order to power the air compressor. Power of this compressor depends on the flow rate, $\dot{m}_{B 1}$ and temperature, $T_{B 1}$, of the air at the inlet to ASU, average specific heat, $\left(\widetilde{c}_{p}\right)_{A C}$, compressor pressure ratio, $\beta$, adiabatic exponent of the air in compressor, $\kappa_{A C}$, isentropic, $\eta_{i A C}$, and mechanical, $\eta_{m A C}$, efficiency of compressor, according to equation:

$$
N_{A C}=\dot{m}_{B 1} \cdot\left(\widetilde{c}_{p}\right)_{A C} \cdot T_{B 1} \cdot\left[\frac{\beta^{\left(\frac{\kappa_{A C}-1}{\kappa_{A C}}\right)}}{\eta_{i A C} \cdot \eta_{m A C}}\right]
$$

Power of the expander depends on the flow rate of the air at the inlet to ASU, $\dot{m}_{B 1}$, oxygen recovery rate, $R$, oxygen mass content in the air, $\left(g_{O 2}\right)_{B 1}$, average specific heat, $\left(\tilde{c}_{p}\right)_{E X P}$, temperature of gas (retentate) at the inlet to the expander, $T_{B 4}$, rate of reduction of compressor pressure ratio, $\sigma$, compressor pressure ratio, $\beta$, adiabatic exponent of air in compressor, $\kappa_{E X P}$, isentropic, $\eta_{i E X P}$, and mechanical, $\eta_{m E X P}$, efficiency of expander, according to formula:

$$
N_{E X P}=\dot{m}_{B 1} \cdot\left[1-R \cdot\left(g_{O 2}\right)_{B 1}\right] \cdot\left(\widetilde{c}_{p}\right)_{E X P} \cdot T_{B 4} \cdot\left[1-(\sigma \cdot \beta)\left(\frac{\kappa_{E X P}-1}{\kappa_{E X P}}\right)\right] \cdot \eta_{i E X P} \cdot \eta_{m E X P}
$$

During stochiometric calculations, with the knowledge of fuel mass composition (carbon $-61.3 \%$; sulfur $-1.1 \%$; hydrogen $-3.9 \%$; nitrogen $-0.9 \%$; oxygen $-6.5 \%$; water $-17.3 \%$; ash $-9.0 \%$ ), lower heating value (LHV) and an assumed excess oxygen ratio equal to 1.2, the mass flow rate of fuel and oxygen needed for combustion process were determined. Then, for both assumed oxygen recovery rates in ASU, the air flow rate fed to separation unit could be determined. Subsequently, with Eqs. (4), (5) 
and (3), power of the air compressor, expander and entire ASU can be determined. These quantities for oxygen recovery rate equal to $65 \%$ and $95 \%$ are gathered in Table 2 .

Table 2. Results of thermodynamic analysis

\begin{tabular}{|l|c|c|}
\hline \multicolumn{1}{|c|}{ Quantity } & \multicolumn{2}{c|}{ Value } \\
\hline Oxygen recovery rate, $\%$ & 65 & 95 \\
\hline Separated oxygen flow rate, $\mathrm{kg} / \mathrm{s}$ & 117.8 & 109.3 \\
\hline Fuel flow rate, $\mathrm{kg} / \mathrm{s}$ & 58.8 & 54.6 \\
\hline Air flow rate at the inlet to ASU, kg/s & 748.5 & 498.3 \\
\hline Power of the air compressor, MW & 436.7 & 277.4 \\
\hline Power of the expander, MW & 448.0 & 263.7 \\
\hline Auxiliary power of ASU, MW & -11.3 & 13.7 \\
\hline
\end{tabular}

\section{DETERMINATION OF THE MEMBRANE SURFACE AREA}

The surface area of the ionic transport membrane is a very important quantity because it determines the dimensions of membrane module and the entire air separation unit. Besides, with the increase of the surface area, the purchase cost of a membrane is proportionally increasing. The first step in determining this quantity is to determine the unit (i.e. referred to the membrane surface area) flow rate of oxygen permeating through the membrane. The flow rate depends on the oxygen partial pressure on the fed side of the membrane, $\left(p_{O 2}\right)_{F}$, oxygen partial pressure on the recirculated flue gas side, $\left(p_{O 2}\right)_{P}$, membrane constant, $C_{1}$, and membrane surface area, $\mathrm{d} A_{M}$, according to formula:

$$
d J=C_{1} \cdot \ln \frac{\left(p_{O 2}\right)_{F}}{\left(p_{O 2}\right)_{P}} \cdot d A_{M}
$$

The oxygen partial pressure on the feed side of membrane and oxygen partial pressure on the recirculated flue gas side are changing with the length of the membrane (as presented in Fig. 2 and in Eqs. (8)-(10)). Thus, the unit flow rate of oxygen permeating through the membrane is different at different lengths of the membrane. The membrane constant $C_{1}$ depends on the universal gas constant $((M R))$, membrane operating temperature, $T_{M}$, Faraday constant, $F$, membrane thickness, $d$ and ionic conductivity coefficient of membrane material, $\sigma$, (Ito et al., 2007):

$$
C_{1}=\left[\frac{(M R) \cdot T_{M}}{16 \cdot F^{2} \cdot d}\right] \cdot \sigma
$$

For the assumed values: $T_{M}=1123.15 \mathrm{~K}, d=0.0473 \mathrm{~mm}$ and $\sigma=92 \mathrm{~S} / \mathrm{m}$, the membrane constant is equal to $C_{1}=0.1219 \mathrm{~mol} /\left(\mathrm{s} \cdot \mathrm{m}^{2}\right)$ (Ito et al., 2007).

The expression under the logarithm in Eq. (6) is:

$$
\frac{\left(p_{O 2}\right)_{F}}{\left(p_{O 2}\right)_{P}}=\beta \cdot \frac{\left(y_{O 2}\right)_{F}}{\left(y_{O 2}\right)_{P}}
$$

where $\beta$ is the pressure ratio of air, $p_{B 3}$, and recirculated flue gas, $p_{B 8}$, at the second side of membrane. No pressure change of both gases in the membrane module was assumed. Then, it could be assumed, that this pressure ratio was approximately equal to air compressor pressure ratio $\beta=p_{B 2} / p_{B 1} \approx p_{B 3} / p_{B 8}$. It was also assumed that the change of oxygen concentration on both sides of the membrane was linear (Fig 2.): 


$$
\begin{aligned}
& \left(y_{O 2}\right)_{F}=a_{1} \cdot x+b_{1} \\
& \left(y_{O 2}\right)_{P}=a_{2} \cdot x+b_{2}
\end{aligned}
$$

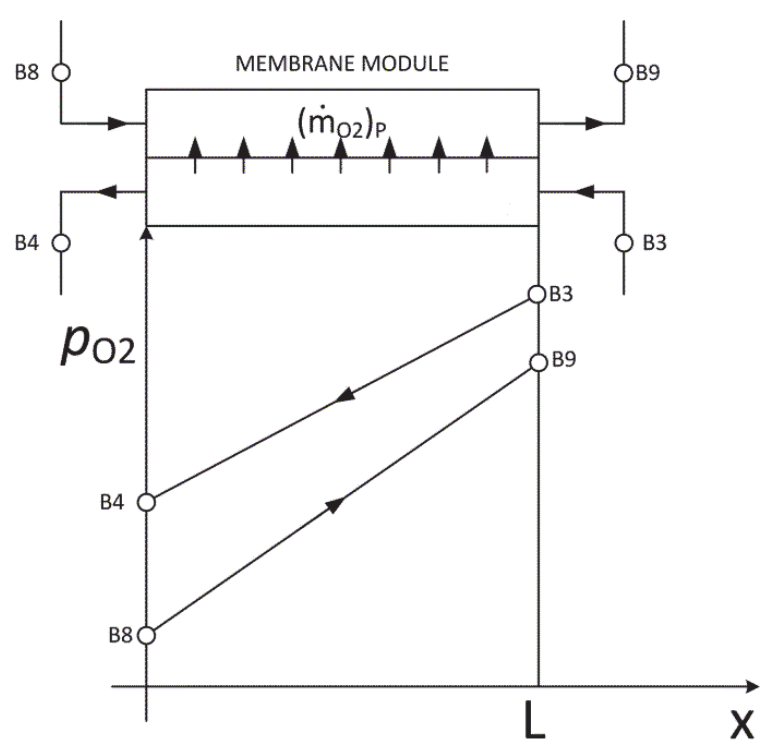

Fig. 2. Distribution of oxygen partial pressure along the length of the membrane (B3 - air; B4 - retentate; B8 - recirculated flue gas; B9 - oxygen-enriched flue gas)

It was assumed that the ionic membrane had a shape of cylinder with a length, $L$, and a radius, $r$. The surface area of the membrane is calculated according to the formula:

$$
A_{M}=2 \cdot \pi \cdot r \cdot L
$$

Using Eqs. (8), (9), (10), (11) and integrating the left side of Eq. (5), the following formula was obtained:

$$
J=C_{1} \cdot 2 \cdot \pi \cdot r \cdot \int_{0}^{L} \ln \left[\frac{a_{1} \cdot x+b_{1}}{a_{2} \cdot x+b_{2}}\right] d x
$$

For integration of the right side of Eq. (12) the coefficients $a_{1}, b_{1}, a_{2}$ and $b_{2}$ are necessary to be designated. Coefficient $b_{1}$ is equal to molar oxygen concentration in the retentate (point B4, Fig.1). It can be determined from the oxygen balance with Eq. (1):

$$
b_{1}=\left(y_{O 2}\right)_{B 4}=\frac{\left(y_{O 2}\right)_{B 3} \cdot(1-R)}{1-R \cdot\left(y_{O 2}\right)_{B 3}}
$$

Using Eq. (9) for $x=L$ the following relationship was formed:

$$
a_{1} \cdot L+b_{1}=\left(y_{O 2}\right)_{B 3}
$$

From Eq. (14) the coefficient $a_{1}$ can be determined:

$$
a_{1}=\frac{\left(y_{O 2}\right)_{B 3}-b_{1}}{L}
$$

Coefficient $b_{2}$ is equal to molar oxygen concentration in recirculated flue gas:

$$
b_{2}=\left(y_{O 2}\right)_{B 8}
$$

Using Eq. (10) for $x=L$ the following equation was obtained: 


$$
a_{2} \cdot L+b_{2}=\left(y_{O 2}\right)_{B 9}
$$

From Eq. (17) the coefficient $a_{2}$ can be determined:

$$
a_{1}=\frac{\left(y_{O 2}\right)_{B 9}-\left(y_{O 2}\right)_{B 8}}{L}
$$

After substituting Eqs (15), (13), (18) and (16) in place of coefficients $a_{1}, b_{1}, a_{2}$ and $b_{2}$ in Eq. (12), integration and many transformations, the following equation was obtained:

$$
J=A_{M} \cdot C_{1} \cdot\left[\ln \beta+\ln \frac{\left(y_{O 2}\right)_{B 3}}{\left(y_{O 2}\right)_{B 8}}+D_{1} \cdot \ln \frac{D_{1}+1}{D_{1}}-D_{2} \cdot \ln \frac{\left(y_{O 2}\right)_{B 9}}{\left(y_{O 2}\right)_{B 8}}\right]
$$

where $D_{1}=\frac{(1-R)}{R \cdot\left[1-\left(y_{O 2}\right)_{B 3}\right]}$ and $D_{2}=\frac{\left(y_{O 2}\right)_{B 9}}{\left(y_{O 2}\right)_{B 9}-\left(y_{O 2}\right)_{B 8}}$.

Calculations with Eq. (12) give correct results when oxygen permeates through the membrane. The requirement for this process is as follows:

$$
\beta \cdot\left[\frac{a_{1} \cdot x+b_{1}}{a_{2} \cdot x+b_{2}}\right]>1
$$

After substituting Eqs. (15), (13), (18) and (16) in place of coefficients $a_{1}, b_{1}, a_{2}$ and $b_{2}$ in Eq. (20) the following formula is obtained:

$$
\beta>\frac{\left[\left(y_{O 2}\right)_{B 9}-\left(y_{O 2}\right)_{B 8}\right] \cdot \frac{x}{L}+\left(y_{O 2}\right)_{B 8}}{\frac{x}{L} \cdot\left(y_{O 2}\right)_{B 3} \cdot\left\{\frac{R \cdot\left[1-\left(y_{O 2}\right)_{B 3}\right]}{1-R \cdot\left(y_{O 2}\right)_{B 3}}\right\}+\frac{\left(y_{O 2}\right)_{B 3} \cdot(1-R)}{1-R \cdot\left(y_{O 2}\right)_{B 3}}}
$$

where $0 \leq \frac{x}{L} \leq 1$

The minimum air compressor pressure ratio as a function of ASU oxygen recovery rate designated according to Eq. (21) is shown in Fig. 3. For all oxygen recovery rates, the maximum value of the right side of this equation within $0 \leq x / L \leq 1$ was found. For the calculations of molar oxygen concentration of the air at the inlet to the membrane module, $\left(y_{O 2}\right)_{B 3}$, equal to $21 \%$, flue gas at the outlet of the membrane module, $\left(y_{O 2}\right)_{B 9}$, equal to $30 \%$ and flue gas at the inlet to the membrane module, $\left(y_{O 2}\right)_{B 8}$, equal to $4.6 \%$ were assumed.

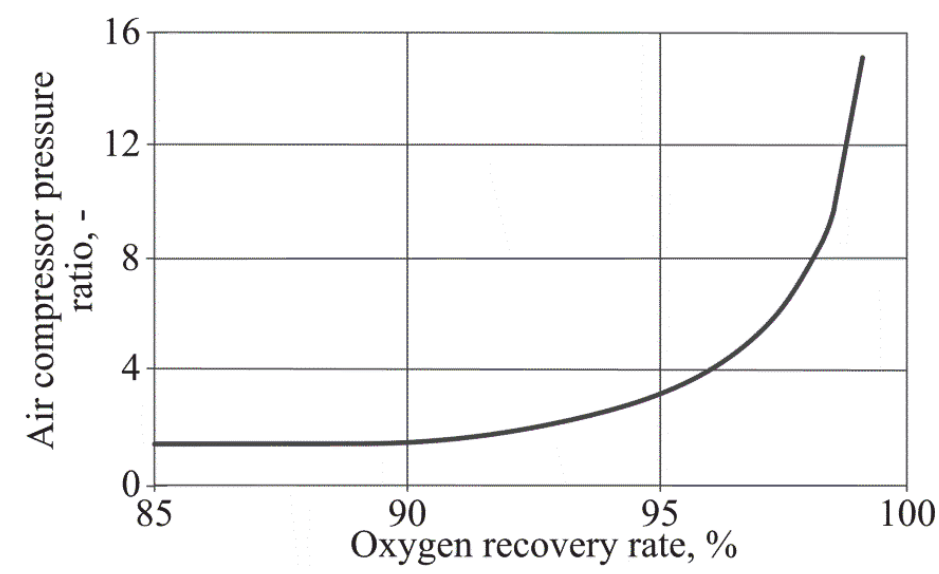

Fig. 3. Minimum air compressor pressure ratio as a function of oxygen recovery rate 
The value of the separated oxygen flow rate, presented in Table 2 and known molar oxygen concentrations, enabled determination of membrane surface area. After transformation of Eq. (18) the following formula can be obtained:

$$
A_{M}=\frac{J \cdot C_{1}^{-1}}{\ln \beta+\ln \frac{\left(y_{O 2}\right)_{B 3}}{\left(y_{O 2}\right)_{B 8}}+D_{1} \cdot \ln \frac{D_{1}+1}{D_{1}}-D_{2} \cdot \ln \frac{\left(y_{O 2}\right)_{B 9}}{\left(y_{O 2}\right)_{B 8}}}
$$

For the assumed membrane constant equal to $C_{1}=0.1219 \mathrm{~mol} /\left(\mathrm{s} \cdot \mathrm{m}^{2}\right)$, and the oxygen recovery rate equal to $65 \%$, the surface area was equal to $9126.2 \mathrm{~m}^{2}$ and for the recovery rate equal to $95 \%$, the surface area was $9740.7 \mathrm{~m}^{2}$.

\section{INVESTMENT COSTS OF THE AIR SEPARATION UNIT}

The investment costs of the air separation unit depend on the coefficient that includes the costs of assembly, connections and utilities supply, $B_{A S U}$, and acquisition costs of an expander, $C_{E X P}$, an air compressor, $C_{A C}$, ionic transport membrane, $C_{M}$, and heat exchangers, $\Sigma C_{H E}$, according to the formula:

$$
K_{A S U}=B_{A S U} \cdot\left(C_{E X P}+C_{A C}+C_{M}+\Sigma C_{H E}\right)
$$

It was assumed that the coefficient $B_{A S U}$ was equal to 1.8. The acquisition cost of the expander, expressed in USD, depends on coefficients $Y_{E X P 1}$ and $Y_{E X P 2}$, isentropic efficiency of expander, $\eta_{i E X P}$, the ratio of gas pressure at the inlet to the expander and gas pressure at the outlet of expander, $\beta_{E X P}=\beta$, gas flow rate, $\dot{m}_{B 4}$, and temperature, $T_{B 4}$, at the inlet to expander, according to the equation:

$$
C_{E X P}=\frac{Y_{E X P 1} \cdot \dot{m}_{B 4} \cdot \ln \beta}{0.93-\eta_{i E X P}} \cdot\left[1+\exp \left(0.0036 \cdot T_{B 4}-Y_{E X P 2}\right)\right]
$$

The acquisition cost of the air compressor, expressed in USD, depends on coefficient $Y_{A C}$, isentropic efficiency of the compressor, $\eta_{i A C}$, compressor pressure ratio, $\beta$, and air flow rate at the inlet to the compressor, $\dot{m}_{B 1}$ :

$$
C_{A C}=\frac{Y_{A C} \cdot \dot{m}_{B 1} \cdot \beta \cdot \ln \beta}{0.93-\eta_{i A C}}
$$

The acquisition cost of ionic transport membrane depends on membrane surface area, $A_{M}$, and the unit cost of membrane, $c_{M}$, according to the formula:

$$
C_{M}=A_{M} \cdot c_{M}
$$

The sum of heat exchanger acquisition costs expressed in USD depends on the coefficient of heat exchanger cost, $Y_{H E}$, and heat exchange surface area of FGH1, $A_{F G H 1}, \mathrm{FGH} 2, A_{F G H 2}$, and $\mathrm{AH}, A_{A H}$ :

$$
\Sigma C_{H E}=Y_{H E} \cdot\left(A_{F G H 1}^{0.6}+A_{F G H 2}^{0.6}+A_{A H}^{0.6}\right)
$$

Heat exchange surface areas of FGH1, FGH2 and $\mathrm{AH}$, calculated with the use of GateCycle computational models, for oxygen recovery rate of $65 \%$ were $47000 \mathrm{~m}^{2}, 900 \mathrm{~m}^{2}$ and $7600 \mathrm{~m}^{2}$, respectively. For oxygen recovery rate of $95 \%$ the surface areas were $43600 \mathrm{~m}^{2}, 800 \mathrm{~m}^{2}$ and $4100 \mathrm{~m}^{2}$, respectively. Quantities expressed by Eqs. (22-26) and assumptions for calculations are presented in Table 3.

As can be noted from the results presented in Table 3, the acquisition costs of the expander and the air compressor are much greater than the acquisition costs of the membrane and heat exchangers. 
Additionally, the increase of the ASU oxygen recovery rate slightly increased the acquisition cost of the membrane, by about 0.47 million EUR, while the investment costs of ASU decreased by about 83.23 million EUR. |The investment costs of the oxy type power plant were designated according to equations presented in (Kotowicz and Michalski, 2013). It was 1711.21 million EUR for $R=65 \%$ and 1456.55 million EUR for $R=95 \%$. As can be noted the share of investment costs of ASU in relation to the total investment costs of the power plant was approximately equal to $13.0 \%$ for the lower oxygen recovery rate. For the higher oxygen recovery rate the share decreases by about 3.4 percentage points.

Table 3. Results and assumptions for investment costs of air separation unit calculations

\begin{tabular}{|c|c|c|c|}
\hline \multicolumn{2}{|r|}{ Quantity } & \multicolumn{2}{|c|}{ Value } \\
\hline & Unit cost of ionic transport membrane, USD $/ \mathrm{m}^{2}$ & \multicolumn{2}{|c|}{1000} \\
\hline Z & Coefficient of heat exchanger cost (FGH1, FGH2 and FGH3), - & \multicolumn{2}{|c|}{2850} \\
\hline$\vec{E}$ & Coefficient $Y_{\text {EXP1 }}-$ Eq. (24), - & \multicolumn{2}{|c|}{2799.6} \\
\hline$\sum$ & Coefficient $Y_{\text {EXP2 }}$ - Eq. (24), - & \multicolumn{2}{|c|}{65.7} \\
\hline$\ddot{\infty}$ & Coefficient $Y_{\mathrm{AC}}$ - Eq. $(25),-$ & \multicolumn{2}{|c|}{41.5} \\
\hline & USD exchange rate, USD/EUR & \multicolumn{2}{|c|}{1.3} \\
\hline \multicolumn{2}{|r|}{ ASU oxygen recovery rate, $\%$} & 65 & 95 \\
\hline \multirow{5}{*}{ 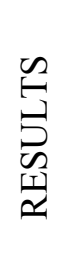 } & Acquisition cost of expander; mln EUR & 104.52 & 60.97 \\
\hline & Acquisition cost of air compressor; mln EUR & 109.45 & 69.52 \\
\hline & Acquisition cost of ionic transport membrane; mln EUR & 7.02 & 7.49 \\
\hline & Sum of acquisition costs of FGH1, FGH2 and AH; mln EUR & 1.99 & 1.77 \\
\hline & Investment costs of air separation unit; mln EUR & 222.98 & 139.75 \\
\hline
\end{tabular}

\section{SUMARY}

In this paper an air separation unit was analyzed. The unit consisted of: a four-end type ionic transport membrane module, an air compressor, an expander fed by gas that remained after oxygen separation and heat exchangers which heated the air and recirculated flue gas to the membrane operating temperature $\left(850^{\circ} \mathrm{C}\right)$. The air separation unit worked in a power plant with electrical power equal to $600 \mathrm{MW}$. The power plant additionally consisted of: an oxy-type pulverized-fuel boiler, a steam turbine unit and a carbon dioxide capture unit. Life steam parameters were $30 \mathrm{MPa} / 650^{\circ} \mathrm{C}$ and reheated steam parameters were $6 \mathrm{MPa} / 670^{\circ} \mathrm{C}$. Thermodynamic analysis was performed for the air separation unit integrated with the oxy-type power plant. During this analysis fuel flow rate, air flow rate, separated oxygen flow rate, power of expander and air compressor elements and auxiliary power of ASU were determined. Calculations were performed for the air compressor pressure ratio equal to 30 and two oxygen recovery rates equal to $65 \%$ and $95 \%$. For the lower recovery rate the expander power exceeded the air compressor power and the excess mechanical power was used to drive the electric generator. For the oxygen recovery rate equal to $95 \%$ there was an opposite situation, thus, it was necessary to use an electric motor to provide the missing mechanical power.

In this paper an equation for calculating the surface area of an ionic transport membrane contained in a four-end type module was formulated. Additionally, an equation determining the minimum air compressor pressure ratio was presented. The pressure ratio was needed to ensure that the required oxygen recovery rate was possible to achieve. The membrane surface area was determined for the oxygen recovery rate equal to $65 \%$ and $95 \%$. The quantity, combined with quantities found in thermodynamic analysis, allowed to estimate the investment costs of the air separation unit. Determination of the methodology of this quantity is presented in the paper. The acquisition costs of 
the expander and the air compressor are much greater than the acquisition costs of the membrane and heat exchangers. The increase of the ASU oxygen recovery rate slightly increased the acquisition cost of the membrane by about $0.47 \mathrm{mln}$ EUR while the investment costs of ASU decreased by about $83.23 \mathrm{mln}$ EUR. Additionally, the share of investment costs of ASU in relation to the total investment costs of the power plant was determined. It was approximately $13.0 \%$ for the lower oxygen recovery rate and to $9.5 \%$ for the higher oxygen recovery rate.

The results presented in this paper were obtained from research work co-financed by the National Centre for Research and Development within a framework of Contract SP/E/2/66420/10 - Strategic Research Programme - Advanced Technologies for Energy Generation: Development of a technology for oxy-combustion pulverized-fuel and fluid boilers integrated with $\mathrm{CO}_{2}$ capture.

\section{SYMBOLS}

$\begin{array}{ll}A & \text { surface area, } \mathrm{m}^{2} \\ B & \text { coefficient, } \\ C & \text { acquisition cost, EUR } \\ \left(\widetilde{c}_{p}\right) & \text { average specific heat, } \mathrm{J} /(\mathrm{kg} \cdot \mathrm{K}) \\ C_{I} & \text { membrane constant, } \mathrm{mol} /\left(\mathrm{s} \cdot \mathrm{m}^{2}\right) \\ c_{M} & \text { unit cost of membrane, } \mathrm{EUR} / \mathrm{m}^{2} \\ d & \text { membrane thickness, } \mathrm{m} \\ F & \text { Faraday constant, } \mathrm{C} / \mathrm{mol} \\ g & \text { mass content, } \\ J & \text { molar flow rate, } \mathrm{kmol} / \mathrm{s} \\ K & \text { investment costs, } \mathrm{EUR} \\ L & \text { membrane length, } \mathrm{m} \\ \dot{m} & \text { mass flow rate, } \mathrm{kg} / \mathrm{s} \\ (M R) & \text { universal gas constant, } \mathrm{J} /(\mathrm{mol} \cdot \mathrm{K}) \\ N & \text { power, } \mathrm{W} \\ p & \text { pressure, } \mathrm{kPa} \\ R & \text { oxygen recovery rate, } \\ r & \text { membrane cylinder radius, } \mathrm{m} \\ T & \text { temperature, } \mathrm{K} \\ Y Y & \text { coefficients, } \\ y & \text { molar content, }\end{array}$

Greek symbols

$\beta \quad$ compressor pressure ratio,

$\eta \quad$ efficiency,

$\kappa \quad$ adiabatic exponent,

$\sigma \quad$ reduction rate of compressor pressure ratio, $-/$ ionic conductivity coefficient of membrane material, $\mathrm{S} / \mathrm{m}$

Superscripts

$A C \quad$ air compressor

$A H \quad$ air heater

$A S U \quad$ air separation unit

EM electric motor

EXP expander 


$\begin{array}{ll}F G H & \text { flue gas heater } \\ G & \text { generator } \\ H E & \text { heat exchanger } \\ i & \text { isentropic } \\ M & \text { membrane } \\ m & \text { mechanical } \\ O_{2} & \text { oxygen } \\ P & \text { permeating }\end{array}$

\section{REFERENCES}

Bartela Ł., Skorek-Osikowska A., Kotowicz J., 2014. Thermodynamic, ecological and economic aspects of the use of the gas turbine for heat supply to the stripping process in a supercritical CHP plant integrated with a carbon capture installation. Energy Convers. Manage., 85, 750-763. DOI: 10.1016/j.energy.2014.01.015.

Bredesen R., Jordal K., Bolland A., 2004. High-temperature membranes in power generation with $\mathrm{CO}_{2}$ capture. Chem. Eng. Process. Process Intensif., 43, 1129-1158. DOI: 10.1016/j.cep.2003.11.011.

Czakiert T., Muskała W., Jankowska S., Krawczyk G., Borecki P., Jesionowski L., Nowak W., 2012. The effect of oxygen concentration on nitrogen conversion in oxy-fuel CFB environment. Proc. of the 21st International Conference on Fluidized Bed Combustion. Naples, Italy, 3-6 June 2012, 495-502.

Darde A., Prabhakar R., Tranier J-P., Perrin N., 2009. Air separation and flue gas compression and purification units for oxy-coal combustion systems. Energy Procedia, 1, 527-534. DOI: 10.1016/j.egypro.2009.01.070.

Dryjańska A., 2013. Thermodynamic analysis of supercritical power plant with a fluidized bed boiler (CFB) OXY-type. Rynek Energii, 104, 11-15 (in Polish).

Engels S., Beggel F., Modigell M., Stadler H., 2010. Simulation of a membrane unit for oxyfuel power plant under consideration of realistic BSCF membrane properties. J. Membr. Sci., 359, 93-101. DOI: 10.1016/j.memsci.2010.01.048.

Gambini M., Vellini M., 2012. Oxygen transport membranes for ultra-supercritical (USC) power plants with very low $\mathrm{CO}_{2}$ emissions. J. Eng. Gas Turbines Power, 134, 081801-10. DOI: 10.1115/1.4006482.

Ito W., Nagai T., Sakon T., 2007. Oxygen separation from compressed air using a mixed conducting perovskitetype oxide membrane. Solid State Ionics, 178, 809-816. DOI: 10.1016/j.ssi.2007.02.031.

Janusz-Szymańska K., Kotowicz J., 2011. Analysis of $\mathrm{CO}_{2}$ membrane separation in the ultra-supercritical coal fired power plant. Rynek Energii, 94, 53-56 (in Polish).

Janusz-Szymańska K., 2012. Economic efficiency of an IGCC system integreted with CCS installation. Rynek Energii, 102, 24-30 (in Polish).

Kotowicz J., Janusz K., 2007. Manners of the reduction of the emission $\mathrm{CO}_{2}$ from the energetic processes. Rynek Energii, 68,10-18 (in Polish).

Kotowicz J., Chmielniak T., Janusz-Szymańska K., 2010. The influence of membrane $\mathrm{CO}_{2}$ separation on the efficiency of a coal-fired power plant. Energy, 35, 841-850. DOI: 10.1016/j.energy.2009.08.008.

Kotowicz J., Janusz-Szymańska K., 2010. The influence of $\mathrm{CO}_{2}$ membrane separation on the operating characteristics of a coal-fired power plant. Chem. Process Eng., 31, 681-697.

Kotowicz J., Janusz-Szymańska K., 2011. Influence of $\mathrm{CO}_{2}$ separation on the efficiency of the supercritical coal fired power plant. Rynek Energii, 93, 8-12 (in Polish).

Kotowicz J., Łukowicz H., Bartela Ł., Michalski S., 2011. Validation of a program for supercritical power plant calculations. Arch. Thermodyn., 32, 81-89. DOI: 10.2478/v10173-011-0033-1.

Kotowicz J., Michalski S., 2013. Methodologies for determining efficiency and break-even price of electricity for an oxy type power plant with a high temperature membrane for air separation, In: Węglowski B., Duda P. (Eds.), Analiza systemów energetycznych. Wydawnictwo Politechniki Krakowskiej, Krakow, 171-189.

Kotowicz J., Sobolewski A., Iluk T., 2013. Energetic analysis of a system integrated with biomass gasification. Energy, 52, 265-278. DOI: 10.1016/j.energy.2013.02.048.

Liszka M., Ziębik A., 2010. Coal-fired oxy-fuel power unit - Process and system analysis. Energy, 35, $943-951$. DOI: 10.1016/j.energy.2009.07.007. 
Pfaff I., Kather A., 2009. Comparative thermodynamic analysis and integration issues of CCS steam power plant based on oxy-combustion with cryogenic or membrane based air separation. Energy Procedia, 1, 495-502. DOI: 10.1016/j.egypro.2009.01.066.

Pipitone G., Bolland O., 2009. Power generation with $\mathrm{CO}_{2}$ capture: technology for $\mathrm{CO}_{2}$ purification. Int. J. Greenhouse Gas Control, 3, 528-534. DOI: 10.1016/j.ijggc.2009.03.001.

Skorek-Osikowska A., Bartela Ł., 2010. Model of a supercritical oxy-boiler -analysis of the parameters. Rynek Energii, 90, 69-75.

Skorek-Osikowska A., Janusz-Szymańska K., Kotowicz J., 201). Modeling and analysis of selected carbon dioxide capture methods in IGCC systems. Energy, 45, 92-100. DOI: 10.1016/j.energy.2012.02.002.

Skorek-Osikowska A., Kotowicz J., Janusz-Szymańska K., 2012. Comparison of the energy intensivity of the selected $\mathrm{CO}_{2}$-capture methods applied in the ultra-supercritical coal power plants. Energy Fuels, 26, 6509-6517. DOI: $10.1021 /$ ef201687d.

Skorek-Osikowska A., Bartela Ł., Kotowicz J., Job M., 2013. Thermodynamic and economic analysis of the different variants of a coal-fired, $460 \mathrm{MW}$ power plant using oxy-combustion technology. Energy Convers. Manage., 76, 109-120. DOI: 10.1016/j.enconman.2013.07.032.

Skorek-Osikowska A., Bartela Ł., Kotowicz J., Sobolewski A., Iluk T., Remiorz L., 2014. The influence of the size of the CHP system integrated with a biomass fuelled gas generator and piston engine on the thermodynamic and economic effectiveness of electricity and heat generation. Energy, 67, 328-340. DOI: 10.1016/j.energy.2014.01.015.

Statistics of Polish electroenergetic sector, 2013. The Energy Market Agency, Warsaw.

Received 29 November 2015

Received in revised form 23 May 2016

Accepted 02 June 2016 